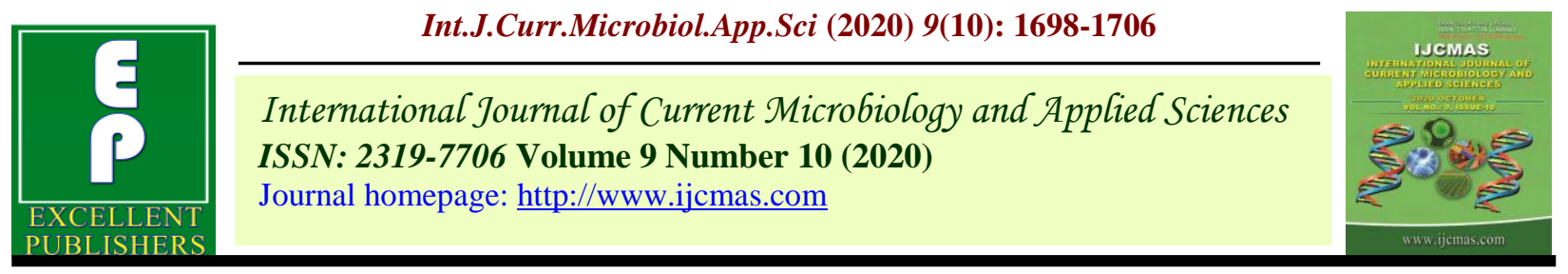

\title{
Cultural, Morphological and Molecular Characterization of Fusarium verticillioides causing Maize Ear Rot under Punjab Condition
}

\author{
Kiranjot Kaur $^{1 *}$, Jaspal Kaur ${ }^{2}$, Anita Puyam ${ }^{3}$ and Karmjit Singh ${ }^{4}$ \\ ${ }^{1}$ Department of Agriculture, Khalsa College Amritsar (143002), India \\ ${ }^{2}$ Department of Plant Breeding, Punjab Agricultural University, Ludhiana, Punjab, India \\ ${ }^{3}$ Department of Plant Pathology, Rani Lakshmi Bai Central Agricultural University, Jhansi \\ (284003), India \\ ${ }^{4}$ University College of Agriculture, Guru Kashi University, Talwandi Sabo (151302), India \\ *Corresponding author
}

\section{A B S T R A C T}

\section{Keywords}

Maize ear rot, $F$. verticillioides, Sporodochia, VERT 1 \& VERT

2, Species specific primers

Article Info

Accepted: 15 September 2020 Available Online: 10 October 2020

\begin{abstract}
Maize ear rot caused by $F$. verticillioides which is prevalent on maize under Punjab conditions. The symptoms appear as white-pink fungal growth and causes "starburst" pattern of white streaks on the kernels. Thirty Fusarium isolates were isolated from the infected maize plant from different agro-chemical zones of Punjab. They are characterized on the basis of morphological, cultural characters and growth rate on Potato dextrose agar (PDA). The isolates produced micro-conidial $4.0-33.0 \mu \mathrm{m} \times 2.4-3.3 \mu \mathrm{m}$ on PDA and macrocondia of 37.0-55.0 $\mu \mathrm{m} \times 4.0-4.2 \mu \mathrm{m}$ on Carnation leaf agar (CLA). Formation of sporodochia was observed on the Carnation leaf agar (CLA). The production of chalmydospores was not observed in any of the isolates. Isolates were grouped into three categories based on colony color and conidial size. The micro-conidial chains production was also observed on water agar infused with 0.2 perent $\mathrm{KCl}$. Genomic DNA was extracted and was subjected to Polymerase chain reaction (PCR) by using species specific primers (PRO 1 PRO2, VER 1 VER2, VERT 1 VERT 2 and SUB1 SUB2). Out of thirty 27 isolates were confirmed as $F$. verticillioides as they gave single amplicon of $800 \mathrm{bp}$ with primer pair VERT 1 \& VERT 2 specific for $F$. verticillioides.
\end{abstract}

\section{Introduction}

Maize (Zea mays L). under family Gramineae, is the world's important crop that ranks third after rice and wheat with respect to area and production. It is one of the most versatile emerging crops having wider adaptability under varied agro-climatic conditions. There are various major constraints in the maize production both abiotic and biotic stress which not only affects the yield but also the quality of the produce as well. Among the biotic stress the various diseases caused by fungi, bacteria, viruses, mycoplasma like organisms and nematodes attack maize crop.

Diseases like root rot, stalk rot, and seedling blight causes heavy losses every year by deteriorating the quality and quantity of grains. Maize crop are attacked by several pathogenic species of Fusarium belonging to 
section Liseola including $F$. proliferatum, $F$. graminearum and $F$. anthophilium (Baired et $a l .$, 2008). Fusarium ear rot (FER) is caused by species within the Gibberalla fujikuroi species complex (GFSC), especially $F$. proliferatum and Gibberella ear rot (GER) is caused by Gibberella zeae, the telomorphic stage of the $F$. graminearum species complex (FGSC) (Bampi et al., 2012).

Among all the Fusarium species, $F$. verticillioides is most prevalent on maize worldwide (Leslie and Summerells 2006). About 7-17 percent of reduction in the quantity and quality of the maize was due to the favourable conditions for the diseases (Nagy et al., 2006). F. verticillioides is an endophyte of maize which established longterm associations with the plant (Pitt and Hocking 1999). Due to the disease, the ear yields poor grain quality contaminated with mycotoxins, which represent a threat to both humans and animals (Logrieco et al., 2002; Munkvold 2003). The major symptom of the disease is white-pink fungal growth on kernels and causes "starburst" pattern of white streaks on the cap of the kernel or along the base (Wang et al., 1991). Both the morphological and molecular identification is required for the identification of Fusarium species.

The morphological identification of the plant pathogenic fungi is the initial step and the most difficult pace for the identification. The morphological identification is not adequate for the Fusarium species due to similar characteristic like mycelia pigmentation and shape of the conidia.

For accurate and rapid identification Polymerase chain reaction (PCR) using species specific primer is becoming one of the most effective method (Zheng and Ploetz 2002).

\section{Materials and Methods}

\section{Fungal Isolation, Purification and Preservation}

The ear rot infected samples were collected from different maize growing districts of Punjab (Hoshiarpur, Shaheed Bhagat Singh Nagar, Ropar, Jalandhar, Ludhiana, Gurdaspur and Karputhala). Isolations of the fungi associated with maize ear rot were done from the infected grain samples by using standard procedure. Four surface sterilized grains were placed equidistantly on potato dextrose agar (PDA) in each Petri plate under complete sterile and aseptic conditions. Plates were incubated at $25 \pm 2^{\circ} \mathrm{C}$ in a BOD incubator. The cultures obtained were purified and examined microscopically to identify the fungi associated with ear rot. Different isolates of Fusarium spp. were purified by single spore culture method and multiplied on PDA slants for further studies. Finally 30 isolates of Fusarium were obtained as F1-F30 and preserved them in slants containing PDA and sterilized soil for further studies.

\section{Cultural and Morphological Characterization}

\section{Morphological characteristics}

For studying the morphology of microconidia, conidiophores and measuring the size, each isolate was grown separately in Petri-dish on water agar amended with $\mathrm{KCl}$. Morphology of macro-conidia and formation of sporodochia were studied using Carnation leaf agar medium (CLA). Slide were prepared and observed under microscope (Leica DM 3000). For studying the macro-conidia and sporodochia, CLA media was prepared as per protocol (Leslie and Summer all 2006). The species were identified morphologically based on "The Fusarium Laboratory Manual" (Leslie and Summerall 2006). The size of 
conidia was measured for each isolate separately at $40 \mathrm{X}$ by using image analyzer software. For observation of colony color, pigmentation and exudation, $5 \mathrm{~mm}$ mycelia disc from actively growing culture of each isolate was cut off with the help of cork borer and inoculated on the centre of the petri plate containing PDA medium. After inoculation, petri plates were incubated at the $25 \pm 2^{\circ} \mathrm{C}$. Each isolate was replicated thrice. Colony diameter was recorded for 15 days at alternate intervals, thereafter colony color, pigmentation for each isolates and production of exudation was recorded.

\section{Identification of Fusarium spp. by PCR using Species Specific Primers}

\section{Culture preparation and DNA extraction}

Thirty morphologically identified Fusarium isolates were grown on $100 \mathrm{ml}$ liquid medium (Potato Dextrose Broth) in $250 \mathrm{ml}$ flasks for 10 days at $25 \pm 2{ }^{\circ} \mathrm{C}$ incubation. After 10 days of incubation the fungal mycelia mat was harvested by filtering with pre-weighed filter paper (Whatman No.1). Genomic DNA was extracted from purified 30 cultures by using mini-prep CTAB method (Murray and Thompson 1980). Quantity and quality of DNA was checked by Thermo Scientific NanoDrop $^{\mathrm{TM}} \quad 1000 \quad$ spectrophotometer (Thermo Scientific, Wilmington, USA). Quality of DNA samples was also tested on 0.8 per cent (w/v) agrose gel. Single high molecular weight band represented good quality of DNA.

\section{PCR amplification (Species specific primers)}

The genomic DNA of all the 30 isolates were subjected to amplification using the species specific primers namely VERT 1 VERT 2 (Patino et al., 2004), VER1 VER 2, PRO 1 PRO 2 and SUB 1 SUB 2 (Mule et al., 2004).
PCR reaction were carried a total volume of $25 \mu 1$ reaction mixture, containing DNA sample, 10X PCR buffer, $2.5 \mathrm{~m} \mathrm{M} \mathrm{MgCl}$, $0.25 \mathrm{~m} \mathrm{MdNTP}$ mix, $20 \mathrm{pmol} / \mathrm{ml}$ of each forward and reverse primer and $0.40 \mu \mathrm{l}$ $(30 \mathrm{U} / \mu \mathrm{L})$ of Taq DNA polymerase was prepared. For PCR, initial denaturation was set at $94^{\circ} \mathrm{C}$ for $5 \mathrm{~min}$ followed by 35 cycles of denaturation at $94^{\circ} \mathrm{C}$ for $1 \mathrm{~min}$, primer annealing at $58^{\circ} \mathrm{C}$ for $1 \mathrm{~min}$ and primer extension was set $72^{\circ} \mathrm{C}$ for $1.30 \mathrm{~min}$ and final extension at $72^{\circ} \mathrm{C}$ for $8 \mathrm{~min}$ followed by cooling at $4{ }^{\circ} \mathrm{C}$. PCR products $(10 \mu \mathrm{l})$ were loaded at $1.0 \%$ Agarose gel containing ethidium bromide along with the standard $1 \mathrm{~kb}$ bp DNA ladder (Promega) and subjected to gel electrophoresis at $10 \mathrm{X}$ TBE buffer at constant voltage of $5 \mathrm{Vcm}$ for about 1 hour. After electrophoresis, the gel was visualized under UV transilluminator and photographed using Alpha Innotech Multi Imager gel documentation system software programme from Alpha Innotech, California, USA.

\section{Results and Discussion}

\section{Cultural characterization of} F. verticillioides

\section{On the basis of cultural characters}

All the 30 isolates of $F$. verticillioides show cultural variations on the PDA. The color of the colony varied from white to purple and type of mycelium aerial to compact (Plate 1). On PDA medium, isolates formed aerial mycelia and produced violet pigments ranged from a pinkish orange to dark violet (Nithiyaa and Izzati, 2012). Pigmentation in $F$. verticillioides varied from no pigmentation to dark violet or dark margenta on PDA medium (Leslie and Summerell, 2006).

\section{On the basis of colony diameter}

The colony diameter was recorded for 15 days at alternate intervals till the fungus fully 
covered the Perti dish (Table 2). Most of the isolates (F1, F3, F4-F6, F9-F13, F15-F22 and F24-F3) except four isolates viz., F2, F8, F14 and F23 fully covered the Petri dish after 7 days of inoculation. Potato dextrose agar was used for morphological appearances and colony colorations by Nelson et al., 1983. On the basis of colony diameter and average growth rate/day all isolates were categorized into 2 categories (Table 2).

Category I having isolates F3 and F4 with mean colony diameter 60.00-70.00 and average growth rate of $7.50-9.00 \mathrm{~mm} /$ day. Category II consisted of isolates F1-F2, F5F30 with mean colony diameter 70.00-80.00 and average growth rate of 9.10-10.50 $\mathrm{mm} /$ day.

\section{Morphological characteristics of Fusarium} spp.

The average size of microconidia ranged from 4.0-33.0 $\mu \mathrm{m} \times 2.4-3.3 \mu \mathrm{m}$ and shape varied from oval to club with flattened base and usually 0 -septate. The micro-conidia were abundant in aerial mycelia, formed long chains or false head attached at monophialides branches and cultures did not produce chlamydospores (Li et al., 2006). The average size of macroconidia ranged from 37.0-55.0 $\mu \mathrm{m} \times 4.0-4.2 \mu \mathrm{m}$ and the shape were curved, tapered to a point, notched or foot shaped and usually 3 to 5 septate (Plate 2 ). The fungus produces a copious amount of single-celled micro-conidia and plentiful amount of septate macro-conidia (Li et al., 2006).

The macro-conidia and sporodochia were produced on carnation leaf agar medium by all the isolates. Three types of media i.e., carnation leaf agar (Fisher et al., 1982), potato dextrose agar (Nelson et al., 1983), $\mathrm{KCl}$ medium (Fisher et al., 1983) were used for identification of the Fusarium species.

The conidial chains having $\mathrm{V}$-shaped pairs appear to give a "rabbit ear" like structure (Leslie and Summerell, 2006). None of the isolate produced chlamydospores in culture. Chains of micro-conidia were present and chalmydospores were absent on the isolates of Fusarium (Bashyal et al., 2015).

Table.1 Sequence of Species specific primers

\begin{tabular}{|c|c|c|c|}
\hline Primer name & Sequence & Product size (bp) & Reference \\
\hline $\begin{array}{l}\text { VERT } 1 \\
\text { VERT } 2\end{array}$ & $\begin{array}{l}\text { GTCAGAA TCCATGCCAGAACG } \\
\text { CACCCGCAGCAAT CCATCAG } \\
\text { Specific for } F . \text { verticillioides }\end{array}$ & 800 bp & $\begin{array}{l}\text { Patino et al } \\
(2004)\end{array}$ \\
\hline $\begin{array}{l}\text { VER1 } \\
\text { VER } 2\end{array}$ & $\begin{array}{l}\text { CTTCCTGCGATGTTTCTCC } \\
\text { AATTGGCCATTGGTATTATATATCTA } \\
\text { Specific for } F \text {. verticillioides }\end{array}$ & $578 \mathrm{bp}$ & \multirow{3}{*}{$\begin{array}{l}\text { Mule et al } \\
(2004)\end{array}$} \\
\hline $\begin{array}{l}\text { PRO } 1 \\
\text { PRO } 2\end{array}$ & $\begin{array}{l}\text { CTTTCCGCCAAGTTTCTTC } \\
\text { TGTCAGTAACTCGACGTTGTTG } \\
\text { Specific for } F \text {. proliferatum }\end{array}$ & $585 \mathrm{bp}$ & \\
\hline $\begin{array}{l}\text { SUB } 1 \\
\text { SUB } 2\end{array}$ & $\begin{array}{l}\text { CTGTCGCTAACCTCTTTATCCACAGT } \\
\text { ATGGACGTTGGTATTATATCTAA } \\
\text { Specific for } F \text {. subglutinas }\end{array}$ & $631 \mathrm{bp}$ & \\
\hline
\end{tabular}


Table.2 Categorization of Fusarium isolates on the basis of their colony growth on potato dextrose agar medium

\begin{tabular}{|l|l|c|c|}
\hline Category & Isolates & Colony diameter $(\mathbf{m m})$ & Growth rate/day (mm) \\
\hline I & F3, F4 & $60.00-70.00$ & $7.50-9.00$ \\
\hline II & F1-F2, F5-F30 & $70.00-80.00$ & $9.10-10.50$ \\
\hline
\end{tabular}

Table.3 Characterization of $F$. verticillioides isolates on the basis of the microconidia, macroconidia and morphological characteristics

\begin{tabular}{|c|c|c|c|c|c|c|c|c|}
\hline CATEGORY & $\begin{array}{l}\text { Colony } \\
\text { Color* }\end{array}$ & Isolates on PDA & $\begin{array}{l}\text { Types of } \\
\text { mycelium }\end{array}$ & $\begin{array}{c}\text { Micro- } \\
\text { conidia } \\
\text { size range } \\
(\mu \mathrm{m}) * *\end{array}$ & $\begin{array}{c}\text { Macro- } \\
\text { conidia } \\
\text { size range } \\
(\mu \mathrm{m})^{* *}\end{array}$ & $\begin{array}{l}\text { No. of } \\
\text { Septa }\end{array}$ & $\begin{array}{l}\text { Sporodoc } \\
\text { hia*** }\end{array}$ & $\begin{array}{c}\text { Chains } \\
* * *\end{array}$ \\
\hline GRP I & $\begin{array}{l}\text { Milk } \\
\text { white, } \\
\text { White, } \\
\text { Cotton } \\
\text { candy, } \\
\text { Pearl }\end{array}$ & $\begin{array}{l}F(1,2,9,15,19,29) \\
F(14,20,30) F(5,23), \\
F(3,21,25)\end{array}$ & $\begin{array}{l}\text { Compact to } \\
\text { Aerial } \\
\text { Compact } \\
\text { Aerial } \\
\text { Aerial to } \\
\text { Fluffy }\end{array}$ & $\begin{array}{c}(4.00- \\
34.60) \\
\mathrm{x} \\
(2.103 .30) \\
\mu \mathrm{m}\end{array}$ & $\begin{array}{c}(37.10- \\
48.60) \\
x \\
(4.004 .10) \mu \\
m\end{array}$ & $3-5$ & + & + \\
\hline GRPII & $\begin{array}{l}\text { Tyrian } \\
\text { purple, } \\
\text { Viola } \\
\text { purple, } \\
\text { Plum } \\
\text { purple, } \\
\text { Dull } \\
\text { purple, } \\
\text { Blue } \\
\text { Lotus, } \\
\text { Lipstick } \\
\text { purple }\end{array}$ & $\begin{array}{l}F(8,17) \\
F(10,26,27) \\
F(12,16), \\
F(22,28), \\
F(6,18,24), \\
F(7)\end{array}$ & $\begin{array}{l}\text { Compact, } \\
\text { Compact, } \\
\text { Aerial, } \\
\text { Aerial, } \\
\text { Aerial, } \\
\text { Compact }\end{array}$ & $\begin{array}{c}(4.10- \\
27.40) \\
\mathrm{x} \\
(2.40- \\
2.50) \mu \mathrm{m}\end{array}$ & $\begin{array}{c}(37.40- \\
42.90) \\
\mathrm{x} \\
(4.00- \\
4.10) \mu \mathrm{m}\end{array}$ & $4-5$ & + & + \\
\hline GRPIII & $\begin{array}{l}\text { Maroon, } \\
\text { Egg } \\
\text { plant }\end{array}$ & $\mathrm{F}(4,11,13)$ & Aerial & $\begin{array}{c}(8.40- \\
33.00) \\
x \\
(2.50- \\
2.80) \mu \mathrm{m}\end{array}$ & $\begin{array}{c}(37.50- \\
39.70) \\
x \\
(4.00- \\
4.10) \mu \mathrm{m}\end{array}$ & $4-5$ & + & + \\
\hline
\end{tabular}

*As per colour chart from website www.W3schools.com (-Absent, +Present)

** On PDA medium

$* * *$ Carnation leaf agar (CLA) medium

$* * * *$ On water agar with $2 \% \mathrm{KCl}(-$ Absent, + Present) 
Plate.1 Colony color of different isolates of $F$. verticillioides

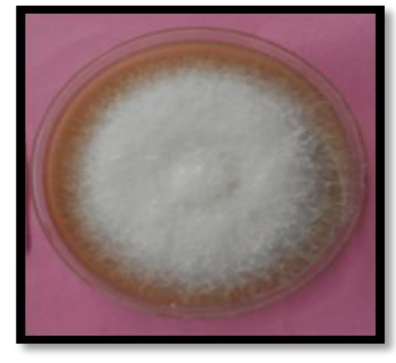

GRP I (White)
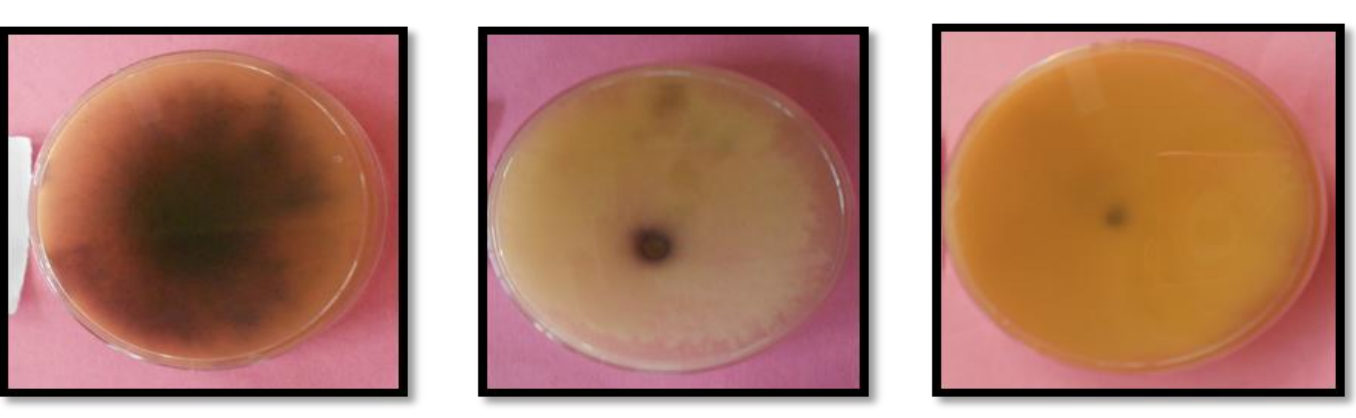

Reverse on PDA
GRP III (Maroon)

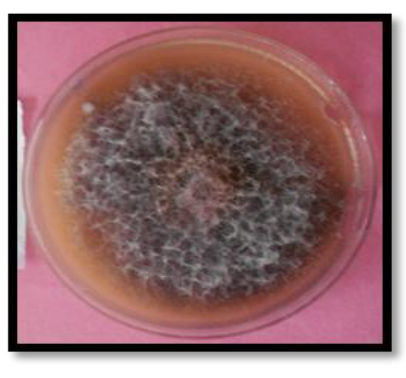

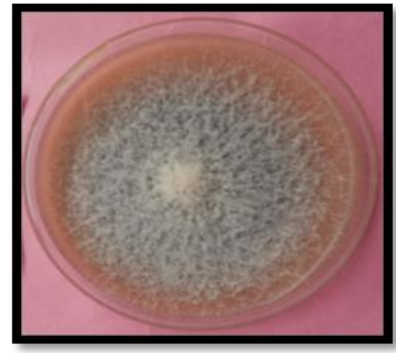

GRP II (Purple)

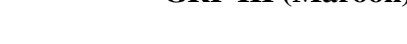

Plate.2 Morphological features observed under the microscope

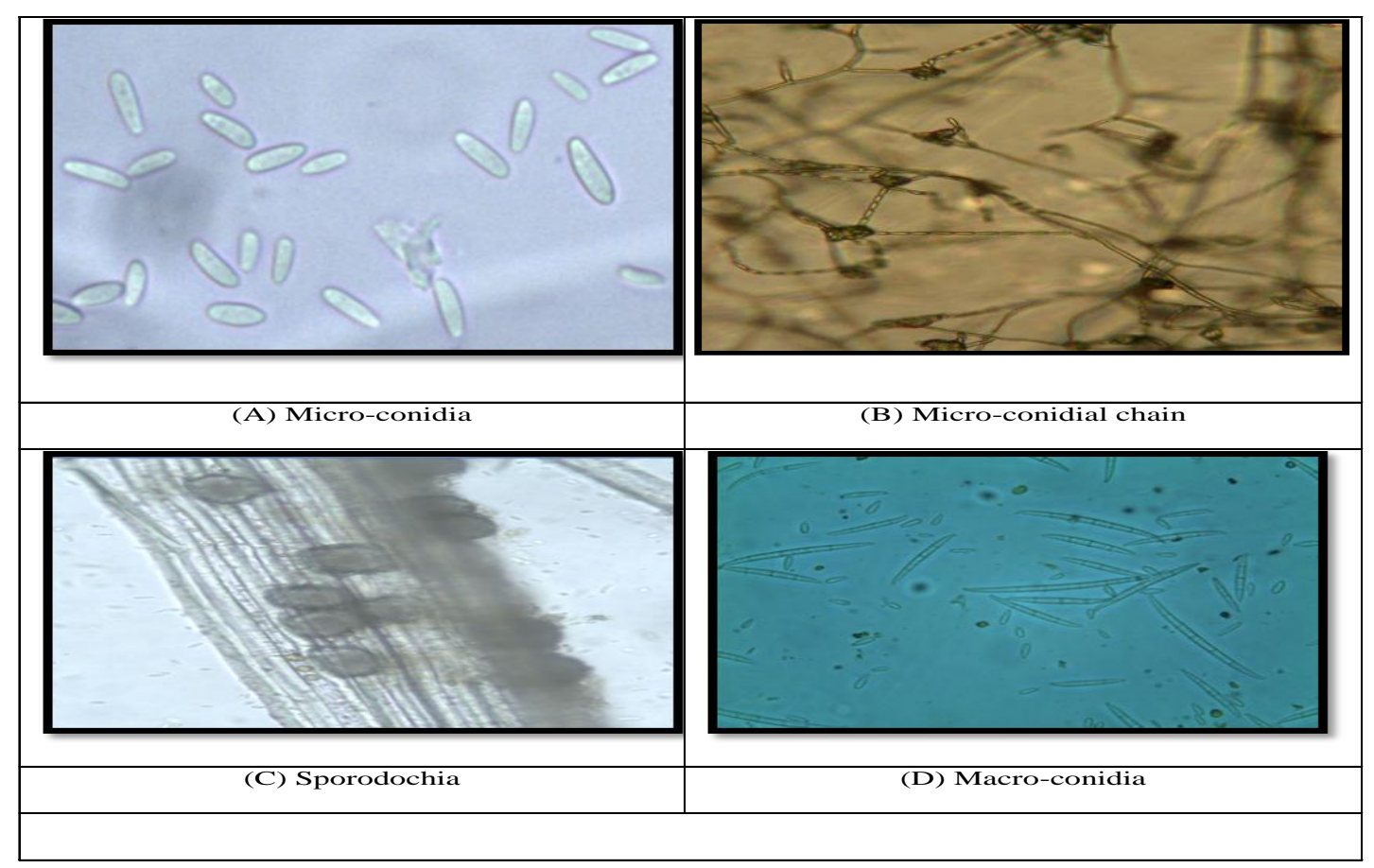


Plate3 DNA amplification of $F$. verticillioides obtained by species specific primer VERT1 and VERT2

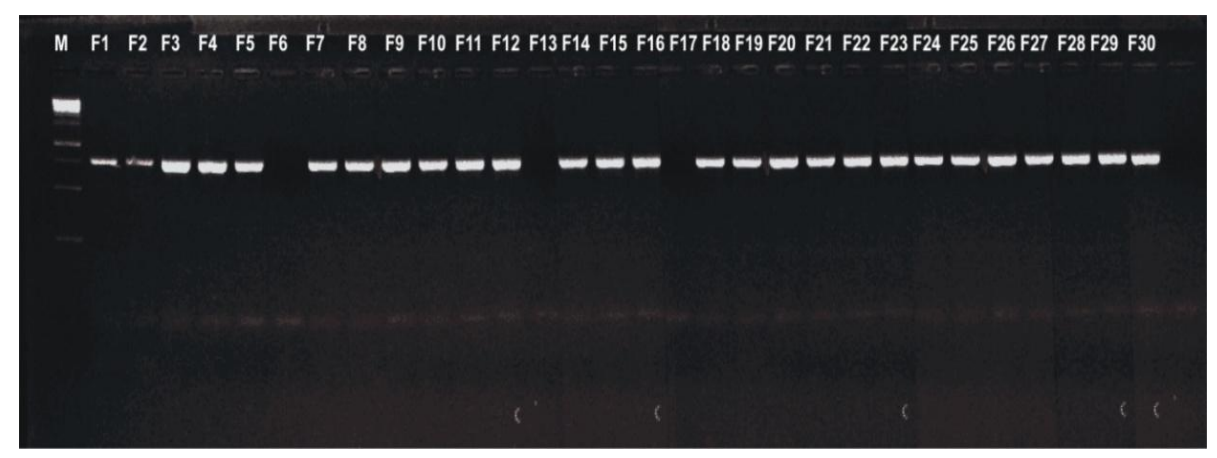

Based on the morphological characteristics isolates were grouped into 3 categories (Table 3). GRP I contain Milk white, White, Cotton candy and Pearl colored colony producing isolates with size of microconidia ranging from (4.00-34.60) $\mathrm{x}(2.10-3.30) \mu \mathrm{m}$ with no septa and macroconidia ranging from (37.1048.60) x (4.00-4.10) $\mu \mathrm{m}$ with 3-5 septa. GRP II comprised of Tyrian purple, Viola purple, Plum purple, Dull purple and Blue Lotus, Lipstick purple colored colony with size of microconidia ranging from (4.10-27.40) $\mathrm{x}$ $(2.40-2.50) \mu \mathrm{m}$ with no septa and macroconidia ranging from (37.40-42.90) $\mathrm{x}$ (4.00-4.10) $\mu \mathrm{m}$ with 4-5 septa. GRPIII consisted of Maroon and Egg plant producing isolates with size of microconidia ranging from (8.40-33.00) $\mathrm{x}(2.50-2.80) \mu \mathrm{m}$ with no septa and macroconidia ranging from (37.5039.70) $\times(4.00-4.10) \mu \mathrm{m}$ with 4-5 septa (Plate 1). On the basis of the cultural and morphological data, it was confirmed from "The Fusarium Laboratory Manual" that the all isolates are $F$. verticillioides.

Molecular characterization of $F$. verticillioides by species specific primers

For further confirmation, all the 30 isolates of $F$. verticillioides were subjected to PCR by using species specific primers VERT1 VERT2, VER1 VER2, PRO1 PRO2 and SUB1 SUB2 (Table 1). Out of the 30 isolates of DNA, got amplified with set of primers VERT1 VERT2 and gave a single amplicon of 800bp (Plate 3). None of the isolate got amplified with the primers specific for $F$. proliferatum and $F$. subglutinas. So, confirmation was made from the morphologically as well as the molecular characterization that the species isolated from the sample is $F$. verticillioides

The pathogen was isolated from the infected samples of maize ear rot collected from different districts of Punjab. All the thirty isolates obtained are characterized on the basis of cultural, morphological and molecular methods. The studies revealed that maize ear rot is caused by $F$. verticillioides in Punjab and no other Fusarium spp were detected. However, the maize ears are also infested with the other species of Gibberella fujikuroi complex, including $F$. proliferatum and $F$. subgultinans (Augin et al., 2013). With reference to "The Fusarium Laboratory Manual," the cultural characteristics (colony color, colony diameter, pigmentation, exudation, type of mycelium) and morphological characteristics (shape and size of micro and macro conidia, presence of micro-conidia in chain and presence or absence of chalmydospores or sporodochia) revealed that maize ear rot is caused by $F$. verticillioides (Leslie and Summerell 2006). From the four different types of species 
specific primers VERT1/ VERT2, VER1 /VER2, PRO1/ PRO2 and SUB1 /SUB2, only VERT1 /VERT2 gave the positive results. VERT1 and VERT2 primers are specific for $F$. verticillioides based on Intergeneric spacer region of Ribosomal DNA (Mirete et al., 2004; Patino et al 2004; Kaur et al., 2014) and have efficiency to discriminate among various other Fusarium spp. Out of 30 isolates, 27 isolates gave the 800 single amplicon with the VERT1/VERT2 species specific primers. Sreenivasa et al., (2008) and Dissanayake et al., (2009) also identified $F$. verticillioides from Indian maize kernels by using VERT1 and VERT2 primer pair. Conclusively, it can be determined that $F$. verticilloides is a predominate Fusarium spp. associated with the disease in Punjab.

\section{References}

Aguin O, Cao A, Pintos C and Santiago R. 2013. Occurrence of Fusarium species in maize kernel grown in northwestern Spain. J Pl Pathol 63: 946-951.

Baird R, Abbas HK, Windham G, Wiliams P, Baird S, Ma P, Kelley R, Hawkins L and Schruggs M. 2008. Identification of select fumonisins production in vitro. Int J Mol Sci 9: 554-570.

Bampi D, Casa RT, Bogo A, Sangoi L, Sachs C, Bolzan JM and Piletti G. 2012. Fungicide performance on the control of macrospora leaf spot in corn. Summa phytopathol 38: 239-250.

Dissanayake ML, Tanaka S and Ito S. 2009 Fumonisins B (1) production by Fusarium proliferatum strains isolated from Allium fistulosum plants and seeds in Japan. Lett Appl Microbiol 48: 598-604.

Fisher NL, Burgess LW, Toussoun TA and Nelson PA. 1982. Carnation leaves as a substrate and for preserving cultures of Fusarium spp. Phytopathologyl 72: 151-153.
Fisher NL, Burgess LW, Toussoun TA and Nelson PA. 1983. Taxonomic importance of micro-conidial chains in Fusarium section Liseola and effects of water potential on their formation. Mycologia 75: 693-698.

Kaur J, Pannu PS and Sharma S. 2014. Morphological Biochemical and molecular characterization of Gibberella fujikuroi isolates causing Bakanae disease of Basmati Rice. $J$ Mycol Plant Pathol 44: 25-30.

Leslie JF, Summerell BA. 2006. The Fusarium, Laboratory Manual. Blackwell Publishing, Ames. 1-369pp.

Logrieco A, Mule G, Moretti A and Battalion A. 2002. Toxigenic Fusarium species and mycotoxins associated with maize ear rot in Europe. Eur J Plant Pathol 108: 597-609.

Li S, Myung K, Guse D, Donkin B, Proctor RH, Grayburn WS and Calvo AM. 2006. FvVE1 regulates filamentous growth, the ratio of micro conidia to macro conidia and cell wall formation in Fusarium verticillioides. Mol Microbiol 62: 1418-1432.

Mirete S, Vazquez C, Mule G, Jurado M and Gonzalez-Jaen MT. 2004. Differentiation of $F$. verticillioides from banana fruits by IGS and EF-1 alfa sequence analyses. Eur J Plant Pathol 110: 515-523.

Murray MG and Thompson WF. 1980. Rapid isolation of high molecular weight DNA. Nucleic Acids Res. 8: 43214325.

Mule G, Susca A, Stea G and Moretti A. 2004. A species specific PCR assay based on the calmodulin partial gene for identification of Fusarium verticilliodes, $F$. proliferatum and $F$. subglutinas. Eur J Plant Pathol 110: 595-612.

Munkvold GP. 2003. Epidemiology of Fusarium diseases amnd their 
mycotoxins in maize ear. Eur J Plant Pathol 109: 705-713.

Nagy E, Has V and Kadar R. 2006. The influence of Fusarium ear infection on the maize yield and quality (Transilvania-Romania). Coтmun Agric Appl Biol Sci 71:1147-50.

Nelson PE, Toussoun TA and Marasas W F O. 1983. Fusarium Species: An illustrated manual for identification. Pennsylvania State University Press; University Park, Pennsylvania, USA.

Nithiyaa P, Izzati AN, Kalsom UY and Salleh B. 2012. Diversity and morphological characteristics of Aspergillus species and Fusarium species isolated from cornmeal in Malaysia. J Trop Agric Sci 35: 103-116.

Patino B, Mirete S, Gonzalez-Jaen MT, Mule G, Rodriguez MT and Vazquez C. 2004. PCR detection assay of fumonisin-producing Fusarium verticillioides strains. J Food Protect
67: 1278- 1283.

Pitt JI and Hocking AD. (Eds) 1999. Fungi and food spoilage. Aspen Publishers, Inc. Gaithersburg, Maryland.

Sreenivasa MY, Das RS, Charith Raj AP and Janardhana G R. 2008. PCR method for the detection of genus Fusarium and fumonisin-producing isolates from freshly harvested sorghum grains grown in Karnataka, India. $J$ Food Saf 28: 236- 247.

Wang E, Merrill AH, Norred WP, Bacon C and Riley RT. 1991. Inhibition of Sphingosine Biosynthesis By Fumonisins, Mycotoxins Produced By Fusarium moniliforme. Faseb $J$ 5: 1605-1608.

Zheng Q and Ploetz R. 2002 Genetic diversity in the mango malformation pathogen and development of a PCR assay. $J$ Pl Pathol 51: 208-216.

\section{How to cite this article:}

Kiranjot Kaur, Jaspal Kaur, Anita Puyam and Karmjit Singh. 2020. Cultural, Morphological and Molecular Characterization of Fusarium verticillioides causing Maize Ear Rot under Punjab Condition. Int.J.Curr.Microbiol.App.Sci. 9(10): 1698-1706.

doi: https://doi.org/10.20546/ijcmas.2020.910.205 